\title{
pÿChildren s Stories Supporting the Development of Critical Literacy and Intercultural Understanding
}

\section{Pesonen, Jaana}

Springer

2019-09-28

pÿPesonen , J 2019, Children s Stories Supporting the Development of Critical Literacy and Intercultural Understanding . in K J Kerry-Moran \& J-A Aerila (eds), Story in Children's Lives : Contributions of the Narrative Mode to Early Childhood Development, Literacy, and Learning . Educating the Young Child: Advances in Theory, Implications for Practice , vol. 16 , Springer , Cham , pp. 275-297 . https://doi.org/10.1007/978-3-030-19266-2_14

http://hdl.handle.net/10138/334638

https://doi.org/10.1007/978-3-030-19266-2_14

acceptedVersion

Downloaded from Helda, University of Helsinki institutional repository.

This is an electronic reprint of the original article.

This reprint may differ from the original in pagination and typographic detail.

Please cite the original version. 


\title{
Chapter 14.
}

Children's Stories Supporting the Development of Critical Literacy and Intercultural Understanding

\author{
JAANA PESONEN \\ University of Helsinki, Finland \\ jaana.j.pesonen@helsinki.fi
}

\begin{abstract}
This chapter examines the possibilities of applying children's storybooks in supporting the development of critical literacy as well as intercultural understanding. Valuing and supporting children's reading is known to provide understanding and empathy towards other human beings. The chapter focuses on theoretical notions related to promoting critical literacies through children's storybooks, but also includes practical examples of utilizing multicultural children's stories. The chapter introduces different strategies that parents and teachers can use to support the development of critical literacy, including critical thinking and understanding multiple perspectives. Focus is especially on young children, because they already are capable of moving beyond what is in front of them on the page. Since children's storybooks offer possibilities for readers to question implicit assumptions about self and others, books can support readers in becoming more culturally aware and sensitive. Consequently, reading storybooks can affect children's intercultural understanding, and the role of storybooks in children's moral development - both shaping and changing attitudes - should be seen as transformative.
\end{abstract}

Key words:

Critical Literacy

Intercultural Understanding

Moral development 


\section{Introduction}

"'It is difficult to live if you trust no one,' a man called Marten said. 'Either you are very sad or very, very independent.' That is why I am a Cat,' I said. 'Because cats are independent.' 'A name will not make anyone a cat,' Marten said. 'But if you are a Cat, then I will call you Cat.' 'I am a Cat,' I said. 'But I feel lonely, rather than independent.' The man stood up. He was as tall as a chimney. His gray beard reached almost to his belly, and it was as messy as a witch's broom. 'It's over now, 'Marten said and his beard flapped. 'What is over?' I asked. 'Loneliness.' Marten bent down in front of me and looked me in the eye. He took me into his arms and held me close. I could feel a big heart beating inside him. 'We are alike,' Marten said. 'We are both hairy, mixed mutts.' 'And lonely,' I barked. 'We were lonely,' the man called Marten said." (A Dog Called Cat, Kontio 2015, np.)

Children's literature brings joy and excitement, it also offers knowledge and supports language development. In addition, children's literature socializes its reader into the culture and society the child lives in. Maria Nikolajeva (2012) claims that children learn social skills, such as understanding other people's emotions from the verbal and visual components of stories. Thus, it is important to value and support children's reading because it provides "a way of helping us understand other human beings" (Nikolajeva 2012, p. 289). The above quotation is from a Finnish children's book called Koira nimeltä Kissa [A Dog Called Cat] (Kontio 2015). The book tells the story of a stray dog called Cat, and a homeless man called Marten. It is visually as well as linguistically a beautiful and powerful story about externality, loneliness, and belonging. It succeeds in representing sensitive, even bold, themes without patronizing or victimizing. For in children's literature, questions of pedagogy intertwine with aesthetic and other values. In consequence, language plays an intricate role in children's books. Perry Nodelman (2010) reminds us how children share language with adults - language in which the complex meanings and values of the culture are written. In this chapter, the social constructivist view of language, meaning that language both represents and constructs our understanding of the social world, is central. Thus, language is seen as circulating the dominant discourses, the discourses of normality, for instance, despite the possible aim of educating against them. As this chapter will discuss in more detail later, in many storybooks, such as A Dog Called Cat, the reader is invited to ponder some of the greatest questions related to humanity - and thus the story offers insights into critical literacy.

This chapter will examine the possibilities of supporting the development of the critical literacy and intercultural understanding of young children through children's storybooks. The focus is on examining how using children's literature could empower children, especially young readers, to engage in critical dialogue which will enable them to recognize, and even examine different worldviews, beliefs and values written into children's literature, as well as in all cultural artifacts (such as cartoons, movies, advertisement, social media, etc.). My goal is to illustrate, with the help of previous research, as well as with practical examples of analyzing children's books, how critical literacy provides an opportunity to discuss personal viewpoints, as well as common ethical values, thus contributing to the moral development of the child. Children's literature is taken as an example of the way in which children, including those not at school yet, can be helped to become critical readers. Therefore, the central questions in this chapter are: How can children's literature support the development of critical literacy in young children? And more specifically in terms of supporting intercultural understanding: How can children's literature be utilized to explore diversity in society, as well as issues of bias and power relations?

To be able to answer the above questions, the chapter begins with a discussion of theoretical notions related to promoting critical literacy. In introducing the potential of critical literacy to support intercultural understanding, the chapter focuses specifically on multicultural children's literature. As will be discussed at greater length later in this chapter, the term multicultural children's literature often implies books presenting ethnic, racial and cultural groups. In the field of children's literature studies, there are many often heated debates related to the different understandings of the term, and according to Mingshui Cai (2002), these debates reveal the sociopolitical nature of the topic. Here multiculturalism is understood to encompass the values, customs, beliefs and practices of people. Multiculturalism needs to be seen in relation to power, which cuts through all levels of society (Botelho \& Kabakow Rudman 2009). Multiculturalism is also about actions, political decisions, encounters and differences, i.e., life 
in all its diverse forms (Huttunen et al. 2005, 19). Often multiculturalism and diversity are used as synonyms. Here cultural diversity refers in a broad sense to dynamic, changing social categorizations, including ethnicity, language, nationality, class, religion/ideology, gender, dis/ability, age and sexuality. Cultural diversity is connected to differences, as people often understand and give meanings to "us," to "our culture," based on comparison to "others," who are thought to be different. This kind of division of the world into "us and them" produces exclusive differences (see e.g. Hall 2013). Another core concept is intercultural understanding, which is comprehended beyond understanding or viewing of cultural differences. In this chapter intercultural understanding encompasses the cognitive, meaning knowledge and awareness as well as the affective domains (see e.g. Perry and Southwell 2001). Intercultural understanding is often described as being part of intercultural learning, thus it also involves aspects of global and societal awareness, as well as the awareness of power structures (e.g. May 1999; Nieto 2010). Both concepts, intercultural understanding and critical literacy, can be traced back to critical pedagogy, and as such have their roots in analyzing questions of equality in educational contexts (e.g. May 1999; Nieto 2010), as well as in examining power relations within language (e.g. Comber 2013; Freire 1970; Luke 2012). As I see it, intercultural understanding and critical literacy share the fundamental bases, such as the examination of values and beliefs, as well as patterns of thinking and behavior.

It is commonly acknowledged that the term multicultural has become so widely used in different contexts, that its meaning has become diverse, as well as fragmentary. However, even more diversified and scattered are the meanings given to the term child. In this chapter, a core belief is that in modernday information societies, children should not be seen as passive recipients, but as active individuals in meaning-making processes. Reynolds (2007) and Murris (2013) demand from adults the acknowledgment that children can be creators, interpreters and innovators when reading, but also when listening to stories. In contemporary research there has been more emphasis on children as competent and critical readers and on individuals with these qualities (see e.g. Murris 2013; Reynolds 2007). This means, according to Murris $(2013,147)$, that children are not seen only as problem-solvers, but also as problem-posers. This kind of approach to childhood, and especially to children's reading, also demands a change in the adult/child hierarchy as it challenges our preconceived understanding of "right" and "wrong" questions and answers. Murris (2014) explains that when children are recognized as problemposers, what is central "are the connections children themselves make between their own lives and identities, and the texts they explore." She highlights that when children are encouraged to share personal, subjective responses, these should not be critically compared or evaluated, since simple "right" or "wrong" answers do not exist (2014).

The above-discussed approach to children and their abilities reminds us that children's literature should not be treated only as a tool for pedagogy. Didactic texts, which presume that the implied reader is in need of instruction, can be counterproductive (Cullingford 1998; Pesonen 2015). When this happens, the intended educational content, for example an anti-racist agenda, is lost. In consequence, even well-intended didacticism can lead to patronizing representations of "others" if morality is strongly underlined in the texts (Pesonen 2015). While this chapter cannot go into in-depth analysis on the questions of didacticism in children's books, it should not be forgotten that texts are as much produced by cultural discourses as by authors (Bradford 2007). Hence, it is not uncommon to find both intended and unintended didacticism in children's books. Especially in the case of storybooks that have representations of multiculturalism, it is crucial to acknowledge that books do not only reflect the dominant cultural understanding of norms, but also reproduce and recirculate these discourses. Concerning this dual role, Clare Bradford (2007) explains that children's books are often caught between discursive pressures. These pressures are due to the socializing agendas that influence the production of these books, the dominant discourses that constitute cultural platitudes, and the counterdiscourses that aim to challenge them. Counter-discourses have the potential to challenge our thinking, and thus they support the development of critical literacy. In this chapter, I begin with an introduction to the principles of critical literacy. After this, I offer an overview to discussions on multiculturalism in children's storybooks. The latter part of this chapter will include practical examples of using storybooks in supporting young children's development of intercultural understanding and critical literacy. At the end of the chapter, I address the role of adults in supporting children's critical reading. 


\section{The principles of critical literacy}

In today's globalized world, many children are exposed to more and more texts, images, videos, news and other forms of communication on a daily basis. To support children, and indeed adults too, in navigating different messages, even confusing and contradictory ones, a variety of skills needs to be taught to individuals to enable them to develop a personal moral landscape (Bajovic and Elliot 2011). Unpacking myths and distortions through reading and writing (Luke 2012) are core skills in the posttruth era, which we live in. Indeed, the need to promote critical literacy is crucial. On a very basic level, critical literacy is important so that young children - as well as all of us! - learn to understand the difference between fact and fiction (Bajovic and Elliot 2011). Practices of critical literacy involve analyzing and critiquing texts in order to understand how language in texts functions to reproduce and maintain unequal power relations in society. Thus, critical literacy develops readers' understanding of texts reflecting values, beliefs and messages about societal norms (Ives and Crandall 2014). In this chapter, the fundamental argument for promoting critical literacy is to view text meaning-making as a process of social construction, connected to various historical, social, and political contexts, and to examine ways in which critical literacy can invite readers to question, explore, and challenge the power relations written in stories.

In practice, critical literacy can be viewed to involve four dimensions: 1) disrupting the commonplace, 2) interrogating multiple viewpoints, 3) focusing on sociopolitical issues, and 4) taking action and promoting social justice (Lewison, Flint and Van Sluys 2002). However, since this chapter focuses on young readers, it is important to emphasize that it is not necessary that all of the four dimensions are included to engage in critical literacy activities. By examining texts utilizing any one of these dimensions, we are engaging in critical literacy (Lewison, Flint and Van Sluys 2002). When focusing on young readers, a fundamental starting point should be that we cannot wait until high school, or even middle school, to teach children to start thinking critically. Young children are already capable of moving beyond what is in front of them on the page. Teachers of young children, including kindergarten teachers, can guide their students through early literacy using critical literacy with the purpose of creating global thinkers who are comfortable dealing with issues and who actively work towards change (Norris, Lucas and Prudhoe 2012). In addition to change, critical literacy is often connected with the idea of empowerment. About fifty years ago, Freire referred to reading both "the word and the world" (1970). Freire here emphasizes that understanding the world - both the local and the global - is the goal of all education. Thus, in this text, literature and reading are seen to have transformative potential; the potential to teach us to better understand the world, as well as our place in it. As Rebecca Powell (1999, p. 29) writes: "Literacy as a moral imperative envisions language as functioning in a transformative way - as a means for seeing the world differently - so that we might begin to construct a more humane and compassionate society."

As discussed above, critical literacy signifies more than reading texts critically. Above all, critical literacy should be understood to include moral development. By moral development I refer to more than the simplistic right/wrong dualism imposed by dominant discourses, but on the ability to question implicit assumptions about the self and the other. Here I follow the example of Baker, Martin and Pence (2008), who connect critical thinking and peace education by suggesting that stories encourage children to develop critical thinking abilities, and an appreciation of diverse cultures. Even more important is the theorizing of Bajovic and Elliot (2011) in their article "The intersection of critical literacy and moral literacy: Implications for practice." Even though Bajovic and Elliot refer to critical literacy and moral literacy as separate concepts, they insightfully show the multiple interconnections between these two, and thus argue strongly how "inherently embedded" moral literacy is in critical literacy. Thus, in this chapter, critical literacy designates about "critical dialogue with texts and world," as Bajovic and Elliot (2011, p. 34) summarize. This means that young children are also seen as competent, active individuals, who depending on their age and abilities need different kinds of support, but nonetheless are able to "read" critically - meaning examine, connect and challenge texts and illustrations. 
As various academics have argued (see e.g. Bajovic and Elliot 2011; Comber 2013; Norris, Lucas and Prudhoe 2012; Reyes-Torres and Bird 2015), including critical literacy as part of the curriculum for young students has various benefits, not only because separating fact from fiction is a crucial skill today, but also because it develops the understanding of social issues, such as inequality. It is also generally agreed that all children need to see aspects of themselves in the curriculum (e.g. Botelho 2015; Cai 2002). Norris, Lucas and Prudhoe (2012) suggest that children need to read or listen to stories about people like themselves in situations similar to their own. However, curriculums should also be pluralistic, and break the monopoly of the mainstream culture (Cai 2002). Literature is one way to bring children's diverse lives into the classroom. Two decades ago, Junko Yokota (1993) argued that multicultural literature helps children to develop an understanding of different backgrounds, and thus influences how they are able to live in a pluralistic society. Yokota also pointed out that teachers need to be able to offer literary experiences that reflect the multitude of backgrounds from which the children come to their classrooms (1993). Consequently, for curriculums in early childhood education and in primary school to support the development of critical literacy and intercultural understanding, children need to hear and read stories which they can identify with, but also stories that expand and challenge their understanding of cultures and histories. Next, I will discuss further the concept of multicultural children's literature, since its complexity is often overlooked.

\section{Putting the focus on multicultural children's literature}

The expression multicultural children's literature is nowadays used in various contexts, and with various meanings. The phrase multicultural children's literature often implies books which present ethnic, racial, and cultural groups. It is argued that these books give children the opportunity to develop their understanding of others, but also "affirm children of diverse backgrounds" (Mendoza and Reese 2001). In discussions, the emphasis is often on how these multicultural children's books present the cultural practices and mores of their characters. Presentations of racial groups, especially within the black/white paradigm, have been central topics, especially in the United States, where race questions are historically rooted in power relations (Broderick 1973; Cai 2002; Botelho and Kabakow Rudman 2009). Racial segregation has strongly influenced, and still influences, South-African children's literature (MacCann and Maddy 2013). On the other hand, in many European countries, different racialized groups, including indigenous people, have not been particularly evident in the majority of children's literature (e.g. Beezmohun 2013; Rastas 2013; Pesonen 2015). Similarly, in Australia, traditionally minorities have not been actively represented in children's books (see e.g. Bradford, 2007). Acknowledging the political history of multiculturalism in children's literature is crucial, otherwise the child and later the adult would struggle to make sense of multiculturalism in the current world-order.

Thus, in this chapter, multiculturalism is understood to encompass the question of "race," as well as other complex and intertwined social categorizations, such as nationality, social class, religion, age, and dis/ability. This approach is supported by the theory of intersectionality, meaning a focus on examining the different social divisions as multiple, overlapping and relational, and avoiding reducing people especially minorities - to single categories. The intersectional approach reminds us about the complex and contradictory nature of power and how it is organized along multiple axes and dimensions. The acknowledgement of these divisions is also relevant because through repetition they affect the existing social, political, and economic structures of societies (see e.g. Crenshaw 2010; Österlund et al. 2011).

Jack Zipes (2002, p. 37) argues that scholars and critics should be more careful when using terms like "multicultural," because to understand differences and contradictions in societies, we should not settle for explaining them with token acknowledgment of different ethnic, class, and regional backgrounds. As early as 1990, John Stephens pointed out that those books that specifically aim to acknowledge current social issues - such as multiculturalism - may well address these issues in a somewhat simplistic way (1990). According to Stephens, the superficial representations of multiculturalism are frequently due to the focalization; difference is often the starting point, and the narratives are focalized by members of the majority culture. Hence, meaning is continuously located within the dominant and/or majority culture's perspective (Stephens 1990). The challenges related to 
representations of multiculturalism call for intercultural understanding, which emphasizes that life, including people and their communities, are complex and diverse. This understanding is in line with Debra Dudek's argument about multiculturalism in Keywords for Children's Literature (2011). For Dudek, multiculturalism in the best cases is about readers negotiating a complex and culturally diverse community. This kind of children's literature can support the child reader in developing a stronger understanding and respect for cultural differences. Dudek points out that in representing multiculturalism, tensions are unavoidable. Thus, books that might aim to strive for acceptance of cultural differences can end up repeating unequal ideological positions, in which one culture has superiority over another (Dudek 2011).

Overall, the intersectional approach to multiculturalism encapsulates what critical literacy also demands: acknowledging the complexity and contradiction of how power is organized along multiple axes and dimensions, thus avoiding single and narrow categorizations. The acknowledgment of categorizations as social constructions is relevant because through repetition such categorizations affect the existing social, political, and economic structures of societies (see e.g. Crenshaw 1991). In addition, it has been argued, especially concerning racial and gender discrimination, that if a single-axis framework - meaning the focus on one social division - is maintained, research fails to recognize how marginalized people are vulnerable on multiple grounds, not only because of race or gender alone (Crenshaw 1991; Dhamoon 2011). Because multiculturalism is a complex topic that often involves tensions (see e.g. Dudek 2011; Pesonen 2015), a critical understanding and the acknowledgment of unequal and racist societal structures is needed when reading multicultural children's books. Even beyond the historical, economic, and political discourses affecting cultural products such as children's literature, we need an awareness of our own subject positions. As Bradford (2011, p. 33) writes, to be able to acknowledge differences respectfully, we have to be willing and able to critically scrutinize our own histories of selfhood and scholarship, to "re-think our agency."

\section{Children's storybooks guiding critical literacy - A practical viewpoint}

I will examine in practice how children's literature can offer opportunities for readers to recognize and examine different worldviews, beliefs and values written into children's literature. Further, I aim to illustrate how critical literacy can also enable ethical and moral discussions, for example, by raising an awareness of stereotypes. Below are suggestions on the kind of matters to consider and pay attention to when encouraging children to become critical readers. However, I also emphasize what McLaughlin and DeVoogd (2004) say about lists of methods in critical literacy never working the same way in all contexts all the time. Consequently, techniques which promote critical literacy always need to be adapted to specific contexts. Thus, all of the questions listed below, on the linguistic, narrative or moral aspects of storybooks are to support the adult - the parent or the teacher, or any care-taker for that matter - when first exploring the text. Hence, the questions are not meant to be posed to the children who are reading, or being read, a storybook. First and foremost, children should feel encouraged to voice their own opinion; thus, in supporting the development of critical literacy, the adult will need to create a safe place for reading and discussions. Here, a safe place means, above all, a possibility for children to speak up, voice their own opinion and be accepted for their ideas. As such, already learning to express one's own view, and justifying it, is a step towards critical literacy.

To discuss the theory of critical literacy further in action, and to illustrate the methods in critical literacy, three storybooks from different countries are taken as examples. The best known of these is Elmer, a British picturebook written and illustrated by David McKee and originally published in $1968 .{ }^{1}$ The Elmer series of 34 books, is among the most translated picturebooks in the world, with around 5 million copies sold in more than 40 languages. Thus, Elmer books are accessible in different countries, and in various languages; they are also suitable even for very young children since the illustrations are colorful and bold and the text provides lots of ideas for discussion. The whole series about Elmer the

\footnotetext{
${ }^{1}$ Elmer was originally published in 1968. In 1989, a slightly different version was published, which is the version used in this article.
} 
Patchwork elephant is about diversity, but especially the first book, Elmer (1986/1989) deals with themes related to difference and belonging. Another book with similar themes is a Finnish children's book, Koira nimeltä kissa [A Dog Called Cat] (Kontio 2015). This book was chosen since it covers many social themes fundamental to humans, such as belonging and loneliness, but also because it is a story about diversity in society. The main characters in the book are homeless. The book received highly positive reviews and it was nominated for the Nordic Council Children and Young People's Literature Prize in 2016. According to the publisher, A Dog Called Cat is for children aged from 3 to 9, however even older children would enjoy and benefit from reading the book. The third storybook chosen to illustrate the methods of critical literacy and support the development of intercultural understanding is a South African picturebook I am Alex by Elena Agnello (2016). I am Alex is a story about Alex's birthday, and it introduces Alex's friends, who represent diversity of many kinds. According to the publisher, the book, aimed for children from 0 to 8 years, is a celebration of difference and tolerance. In all, these three picturebooks share the same themes of difference and friendship. Below I discuss in detail different strategies for using these books to support the development of critical literacy.

\section{Critical literacy in action}

Plot and theme offer various possibilities for initiating a discussion about a book. In the beginning, the adult can open up the discussions with some basic questions, such as "what happens in the story; what is the story about?" All three books are inspiring stories for discussing multiple social themes with the children. To start with, A Dog Called Cat is a story is about a dog called Cat who has learned from very early on to survive independently. Cat's life is lonely, despite her attempts to be independent. After meeting a homeless man, called Marten, she finds friendship, companionship and belonging. I am Alex and Elmer share the same theme of friendship, but the approach is different. In Elmer, it is explained at the beginning how Elmer is part of a large herd of elephants. One night, Elmer starts questioning himself and his place in the herd. After camouflaging his colorful patchwork skin, he becomes, for a moment, the same color as all the other elephants. However, he soon realizes that he enjoys being who he is - a unique individual. In I am Alex, the storyline is also built around the uniqueness of different kinds of people. Alex's birthday party guests include a family with two dads, a Muslim family, a girl called Zia who is in a wheelchair, and others. More than anything, I am Alex is a book that celebrates friendship and diversity. Common topics for discussions for all three books range from "what is friendship?" to "what is uniqueness?" Both Elmer and A Dog Called Cat invite discussion on such topics as "how does it feel to be different/lonely?" and "why are some people lonely?" Books such as A Dog called Cat also invite one to ponder "what is homelessness/richness/poverty?" As I will examine further below, contemporary children's books such as these can succeed in raising multiple, even sensitive themes. Storybooks vary in their approach to topics such as diversity; some avoid giving simple solutions to complex questions, whereas others end up reinforcing unequal power relations. Thus, storybooks create fruitful places for promoting critical literacy.

Language provides insights when examining the story on multiple levels. Starting from the language used, the words can be analyzed: are the words familiar or unfamiliar? are there loaded words, and if so, how are they used? According to the Oxford English Dictionary, loaded refers to items being charged, burdened, and also weighted or biased towards a particular outcome. For example, a word can be detected as "loaded" when it has an insulting tone. However, the stereotype or bias is not necessarily blatant; it could also be subtle, and thus more difficult to detect. Attention should be paid to words such as savage, primitive, backward, and for example, wild, as in most cases they promote a racist discourse. In addition, looking for gendered stereotypes that traditionally reinforce the binary dichotomies of male/female, strong/weak and provider/nurturer, offer insights into the political and ideological discourses written into children's stories (Pesonen 2015). Stereotypes related to gender or to ethnic groups are often thought to be too difficult or too sensitive issues to be dealt with by young readers. However, children start to become aware of such social matters before entering school, thus examining the language of a storybook can offer the first steps towards critical literacy. 
In A Dog Called Cat, loaded words, such as piski [mutt], puliukko, pultsari and spurgu [bum, drunkard] are used in two ways. First, to demonstrate what exclusion feels like. This is done by showing what happens when Cat goes to a dog park to look for friends. She is laughed at when she gives her name: "One noble-spirited Afghan hound told me that I smell like a mixed mutt. -And my noble sense of smell never mistakes when it comes to race and mixed-race, said the noble Afghan and marked the tree with his wee." (Kontio, 2015, np. ${ }^{2}$ ). Teachers and parents can help younger children to make the connection to the early, yet still influential doctrine of racism, according to which physical characteristics, for example genetic or skeletal features, differ so profoundly that different human groupings should not be racially mixed (see e.g. Todorov 2000). Also, in Elmer, the language used invites the reader to ponder the questions of exclusion with reference to racism: "Elmer was different. Elmer was patchwork. Elmer was yellow and orange and red and pink and purple and blue and green and black and white. Elmer was not elephant color." (McKee, 1989). In Elmer, the word "different" refers specifically to color, since the herd Elmer belongs to is described as including young, old, tall, fat and thin elephants: "Elephants like this, that or the other, all different but all happy and all the same colour. All, that is, except Elmer." (McKee, 1989). Language, such as the use of the word "different" in Elmer, offers the possibility of raising questions about difference and sameness, and provides an opportunity to challenge whiteness as the hegemonic norm.

Through the language used, books invite the reader to ponder the themes of friendship, loneliness, and, for example, exclusion, but also offer a different approach. Elmer invites us to ask: Why did Elmer feel different? Why did he try to be like others? Alex invites reflection on one's own family and/or friends: What kind of friends do you have? Why are they all unique? Whereas A Dog Called Cat raises questions such as: Why do the other dogs reject and exclude Cat? How do you think Cat feels when she is discriminated against? Connecting the character's experiences and what it feels like to be discriminated against, facilitate discussions about racism based on religion or skin color. Storybooks also invite the reader to examine critically the power of language. Loaded words, such as "bum" in $A$ Dog Called Cat, which used by an outsider would be insulting, is used by Marten to describe himself. Thus, when Marten owns a derogatory term he uses it to empower himself even though in the dominant discourse it would be marginalizing. More generally speaking, the language in A Cat Called Dog is close to poetic, and the happenings are not overtly explained, which leaves more space for the reader to fill in meanings.

Narration calls for examining the point of view/s portrayed in the story. Questions such as, "whose voice is heard/not heard?" and "how does the narrator tell the story?" can be used to initiate the discussion. In Elmer, the story is told by an omniscient narrator. In A Dog Called Cat the narrator, as well as the focalizer, is the dog called Cat, and the time of narration is close to the events narrated. In $I$ am Alex, the narrator is Alex. Often from such immediately engaging first-person narration it follows that readers will be apt to align themselves with the subject position, and hence the social attitudes occupied by such a protagonist (McCallum and Stephens 2011). Importantly, Cat as a narrator speaks from the position of a minority. As mentioned previously, in children's literature narratives are often focalized by members of the majority culture (see Stephens 1990). Alex's case, however, is more complex, because she represents the dominant discourse in children's literature in general: white, middle-class and with a nuclear family. However, in South Africa, where the book was written and published, Alex does not represent the majority of children. In Alex's story every single guest coming to her party represents some social categorization which is different to her own. Thus, all the guests become representative of different ethnicities, religions, sexual orientations or abilities. As such, I Am Alex offers various opportunities to examine power relations. In A Dog Called Cat the power relations would change, even dramatically, if the narrator described the encounter with Marten from a majority culture's perspective. Marten might become a subject of pity due to his unconventional lifestyle. However, the main characters in both books voice the experience of belonging to minorities, making their relationship equal rather than superior to the other. Thus, narration in general invites the reader to examine critically different power relations portrayed in stories.

\footnotetext{
${ }^{2}$ All three picturebooks analyzed in this chapter are without page numbers. From hereon, I use only the writer's name and the publication year as the reference.
} 
Figure 1: Practical tips for adults in supporting critical literacy for young readers

In A Dog Called Cat and Elmer, the repetitive style of the narration creates interesting opportunities for readers to examine the events of the story. Both Elmer and Cat are insecure about their place, thus questions about belonging are central topics. Elmer goes through feelings of anxiety and self-doubt about being different: “'Whoever heard of a patchwork elephant?' he thought. 'No wonder they laugh at me." (McKee 1989). However, he quickly understands that he does not in fact want to put aside his personal identity. Similarly, Cat changes after meeting Marten. Instead of continuously searching for her place and her identity, Cat starts to see all the beauty around her. This new attitude towards life is apparent, for example, when Cat describes how Marten behaves after drinking his bottle: "Marten began to sing. Sometimes he got up and started to dance too. Then I would bark with joy and jump around him. The silhouette of the city was like an accordion that the wind was playing." (Kontio 2015). The narration in A Dog called Cat succeeds in introducing sensitive issues, such as homelessness, without patronizing or condemning. This, as will be discussed next, provides a lesson in empathy for the reader.

The potential fiction has for teaching even very young children to see with other eyes is a powerful lesson in empathy. This makes children's literature a versatile recourse for initiating dimensions of critical literacy in both formal and non-formal learning environments. Nikolajeva explains how texts can offer "excellent opportunities for mind-reading skills to readers without accomplished verbal literacy, but certainly also contribute to the development of empathy in any reader" (2010, p. 289). She continues that cognitive criticism suggests a neurological basis for the value of reading since it provides a way of helping us understand other human beings (Nikolajeva 2010). Hence, the didactic quality of children's literature in directing social interaction should not be dismissed. Such didacticism includes one of the moral principles of critical literacy, namely engaging both children and adults in evaluating how we should, or should not, treat each other.

As already mentioned above, in A Cat Called Dog and I am Alex, the reader is prone to take the protagonist's subject position due to the first-person narrative, and thus the themes of difference and uniqueness become even more foregrounded. In I am Alex, difference is celebrated. According to the publisher, the storyline is simple and innocent. The publisher, Robin Stuart-Clark, claims how "children don't see race or religion, sexual preference or disability - and nor should they have to." The aim to educate children about intercultural understanding, such as an awareness of different cultural customs, is obvious: "Lina is my friend, and she has many sisters and brothers. On Fridays the family goes to the mosque and their father reads the Koran to them." (Agnello 2016). However, in I am Alex, the individuals are presented solely as examples of different ethnicities, religions or disabilities. Consequently, I am Alex offers a rather one-dimensional view of diversity in society. Multiculturalism is presented solely as a joyful part of life, meaning that the unequal societal structures created by these categorizations are completely ignored. When difference is the starting point of the story, it is more likely that multiculturalism will be represented superficially (cf. Stephens 1990). Superficial representations of multiculturalism can result in minorities being represented as tokenistic characters, as stereotypes, just to make the books "appear multicultural" (Pesonen 2015).

In terms of narration and empathy, I am Alex is the only realistic picturebook of the three which has humans as characters. However, Alex's story offers least in terms of empathy, since all characters, including Alex herself, are introduced rather superficially. While A Dog Called Cat and Elmer have anthropomorphized animal protagonists, they offer a much richer storyline in terms of empathy. In $A$ Cat Called Dog and Elmer, difference results in loneliness, and in Cat's case, in exclusion as well. At the beginning of A Dog Called Cat, Cat explains her search to be independent: "I thought what it meant to be independent, but found only loneliness. I tried to talk with the birds, and find company from the moose. All the animals turned away or sent me away." (Kontio 2015). Since Cat was taught by her mother to trust no one - humans or animals alike: "I was the loneliest dog in the world." Cat ends up 
doubting even herself. This doubt is evident in an illustration of Cat in a shop window, ironically gazing at a cat mask. Cat's confusion over her identity is present throughout the story since she continuously repeats to herself the sentence "Dog whose name was Cat," until she meets Marten. Both Elmer's and Cat's search for a solid identity offers the possibility to discuss self-doubt, or any other insecurities children might bring up. All three books, in their different ways, are stories about identities: Cat and Elmer represent the contemporary notion that identities are fluid, something one can change, whereas in I am Alex, people are introduced as presenting certain identities in which the birthday party becomes a stage to represent people's different identities.

A well-intended call for empathy can also end up reinforcing unequal structures in society. Thus, it is important that Marten, as a homeless man with a drinking problem, is not vilified. Above all, Marten is presented as a kind, caring, and wise person. As such, A Dog Called Cat has rather a different approach to the theme than many other books dealing with homelessness. In Finland, homelessness is not a common topic in children's books; however, in the United States there are several picturebooks as well as young adult's novels that deal with this topic. In 1993 Raymond Kettel wrote an article "Understanding Homelessness Through Children's Books," and listed almost thirty books about homelessness written for children and young adults. More recent publications, such as The Can Man (Williams 2010) and A Shelter in Our Car (Gunning 2004) portray homelessness. Another group of books are those dealing with homeless children, often set in the so-called developing countries. One such example is Homeless Bird (Whelan 2001) set in India. Below I will discuss the possible pitfalls related to presenting "faraway places and cultures" in children's books, as well as other viewpoints that call for the promotion of critical literacy.

When a socially sensitive topic, such as homelessness is dealt with in a storybook, the need for critical literacy is even more significant. Kettel (1993) emphasizes that the valuable lesson that books such as Uncle Willie and the Soup Kitchen (DiSalvo-Ryan 1991) can offer is to teach how to help those living in the streets. Kettel's argument about books which encourage children and young adults "to appreciate their own life situations," as well as develop "more positive attitudes toward those who are homeless," shares the idea of compassion and empathy, however the unequal power relations between individuals or in societies are not discussed or challenged but rather reinforced. Susan L. Stewart (2007, 103) writes insightfully about the "we're fortunate syndrome." She explains that a symptomatic reaction, a somewhat "solipsistic attitude, one where the reader refocuses attention on our lives rather than focusing on the lives of others," can follow when people read about "other" places and cultures. Rather than looking for reasons for homelessness, the moral in A Dog Called Cat calls for humanity, for us to really see each other without prejudices.

As with A Dog Called Cat, in Elmer, the lesson in empathy is foregrounded through experiences of loneliness and exclusion. Despite the rather naïve ending, where other elephants decide that they want to celebrate Elmer's uniqueness with an Elmer's Day every year, the story offers a chance to see through others' eyes. Seeing through others' eyes requires reflection and the questioning of generalizations. Relating to fictional characters will support the development of empathy if the reader can "sample the feelings of another," that is to say, "imagine what the world might look like to another person and to engage with their beliefs" (Fjällström and Kokkola 2015, 297). In all, the whole Elmer series offers many stories that deal with different kinds of social issues. For instance, in Elmer and the Monster (2014) the plot is built around the question of why we are often afraid of the unknown. With a simple but insightful narration, the story invites the reader to consider different viewpoints and to challenge stereotypes. Similarly, Elmer and Aunt Zelda (2006) calls for appreciation of the older generation and could initiate discussion on discrimination based on age.

The role of image is fundamental in picturebooks. Thus, young readers should also be encouraged to examine illustrations critically, for example, by considering the relationship between text and illustrations. Including visual literacy, such as design elements, prepares young children to critically examine images as stories or as components of stories. Discussion with young readers about the meanings produced through illustrations can be initiated with simple questions about the line, color, shape, texture, and other elements of design in the story. Visual elements, or visual codes, can also be analyzed by examining how illustrators create meaning through the use of position, size, perspective, as well as action, movement, facial expressions, and, for example, body gestures (Cotton and Daly 
2015, 100). Mia Österlund, Maria Lassen-Séger and Mia Frank (2011, 66-67) use the term integrated visuality to remind us that illustrations deserve as much attention as texts. Bal (2002) explains that illustration can be considered to be visual texts, and this type of examining of illustration can support the analysis and function as a reminder that lines, motifs, colors, and surfaces, like words, contribute to the production of meaning. Images, like texts, necessitate careful reading (Bal 2002, 26). One fruitful topic for the critical literacy approach is the contradiction between text and illustration. Nikolajeva $(2012,279)$ writes that when there is no overt contradiction between verbal and visual information, our interpretation is more often unequivocal. But when the text and the illustrations are not symmetrical, an element of surprise, even uncertainty, is added to the storyline. Hence, there is also more flexibility and fluidity for the reader to interpret and provide meanings (Pesonen 2017).

Illustrations offer multiple ways to include dimensions of critical literacy, because the illustrations often carry more meaning related to multiculturalism than the words alone (Pesonen 2015, 87). Illustrations can provide information that the textual narratives do not reveal, such as information about age, appearance, and clothes. Through these visual narratives the reader can learn about the class, country and lifestyle, and the cultural and genetic background of an individual. Thus, it is important to be aware of all the meanings and connections to specific cultures, values, and ideologies that the images carry (Nodelman 2010, 15-17, 24). Critical analysis of visual elements is also needed because both contemporary and more dated children's literature illustrations may portray stereotypes related to gender, nationality, and class. Part of this stereotyping comes from illustrating "other" people, often minorities or those from "faraway countries," as the noble savage, or as primitive "children of nature." What follows is the exoticizing, mystifying, and patronizing of people (see e.g. Botelho \& Kabakow Rudman 2009; Bradford 2007; Pesonen 2015). In all three stories analyzed, the illustrations differ in style. In Elmer, the colorful illustrations are central, although the text is equally important in meaning making since the omniscient narrator explains what Elmer or other characters think or feel. In I am Alex, the illustrations are cartoon-like in style. In addition, the images and words tell the same story; thus, $I$ am Alex falls into the category of a symmetrical picturebook (see e.g. Nikolajeva and Scott 2006, 1117).

Figure2. Koira nimeltä kissa (2015) Tomi Kontio, illust. Elina Warsta. Teos. Helsinki.

Figure 3. I Am Alex (2016) Elena Agnello, illust. Adrie Le Roux. Bumble Books, Noordhoek.

Figure 4. Elmer (1986/1989) David McKee. Andersen Press Ltd., London.

In A Dog Called Cat, the illustrations are complementary in style, meaning that they add to the storyline. The illustrator, Elina Warsta, uses colors to emphasize the change in Cat from being lonely and lost to being joyful and optimistic. After the friendship between Cat and Marten begins, the images become warmer in color; blue, green, and grey tones give way to pastels, pink, and red. Details in the illustrations contain humor as well as additional viewpoints to the story. One example of additional meanings through illustrations is when the children - who are told at times to follow Marten and Cat are shown to have masks. However, the children do not wear these animal masks on their face, but appear as though they have been lifted away, as if to symbolize how children do not yet have prejudices like adults and are thus more open minded towards difference. Analyzing the word-picture dynamics enables the reader to focus on textual gaps and silences, such as what is not said but is illustrated, introducing contradictions as well as multiple meanings.

All picturebooks provide material for examining how meanings are produced. However, the complementary, and even more, the expanding picturebooks, where the illustrations provide more complicated narratives than the texts alone, provide a useful arena for practicing critical literacy. Expanding picture book words and images can also provide alternative information or they can contradict each other. Such books also serve as a reminder that picture books have a dual mode (texts and illustrations) in addressing any theme. In other words, in picture books different levels of meaning can be articulated. Hence the "disunity," or even more so, the contradiction, of the texts and illustrations 
is one of the possibilities that a picturebook offers for denaturalizing what is taken as given, namely the status quo stories (Nikolajeva and Scott 2006, 11-17; Pesonen 2015, 88, 105).

Counter-discourses (also called counter-stories, cf. Chaudri and Teale 2013) present things differently, often challenging hegemonic discourses. Marten in A Dog Called Cat is an insightful example of an individual who is often located in the margins of dominant discourses, but through counter-discourse is represented as an active agent rather than as a victim in need of help. The power that counter-discourses carry in presenting things differently is also based on not depicting differences as exoticized and romanticized representations of "other cultures" (Pesonen 2015, 103-105). Counterdiscourses are fundamentally about challenging hegemonic discourses that reproduce overly simplistic, status quo thinking based on stereotypes. In practice, counter-discourses can often be portrayed through illustrations. As explained above, dual meanings are produced in picturebooks, and this is one of the most important literary strategies in creating counter-discourses. Thus, especially in expanding picturebooks, the visual narratives of ethnic, religious, gender, age, or dis/ability differences are illustrated without textual emphasis. Hence, differences as fixed and exclusive do not become reproduced in these stories. The illustrations in A Dog Called Cat, for example, portray a diversity which is not narrated in the text. One such brilliant illustration shows Cat and Marten traveling on the subway. The other people in the subway portray diversity of ethnicity, religion, age and sexual orientation, while the text explains how Cat and Marten traveled from east to west and back again, looking for the best places to sleep, and finding food that people had thrown away.

Another strategy to examine how storybooks can challenge the dominant discourses is to focus on playfulness. Humor and irony in storybooks allow so-called "sensitive themes," such as sexual orientation, to be approached without overt didacticism. Humor and irony are also used to create complex and norm-challenging storylines (Pesonen 2017). In Elmer, humor is clearly a strategy in dealing with topics such as difference. After Elmer covers his colorful patchwork skin with berries, he soon realizes how blending in, and being the same color as all the others, is not the solution. Elmer surprises the other elephants by scaring them off: "The elephants jumped and fell all ways in surprise. "Oh my gosh and golly!" they said - and then saw Elmer, helpless with laughter. (--) "Oh Elmer," gasped an old elephant. "You've played some good jokes, but this has been the biggest laugh of all. It didn't take you long to show your true colours."' (McKee, 1989). Especially in postmodern picturebooks, such as A Dog Called Cat, humor, as well as irony and unexpected occurrences, is a common feature. Even though in A Dog Called Cat Marten, with his long beard and scruffy clothes, does not challenge the visual stereotype of a homeless man, but by proudly taking his place in society, and even further, by challenging our thinking about richness and poorness, the idea of counter-discourse is manifested. As such, counter-discourses allow for participation and agency to be written for those coming from minorities. These kinds of representations of individuals and societies can challenge the idea of cultures as fixed monolithic entities. In consequence, counter-discourses seek to create a diverse and complex story of human experience, without engaging in such themes as tolerance (cf. Dudek 2011).

While this list is in no sense exhaustive, the main intent is to draw attention to the possibilities that children's books offer for developing critical literacy that encompasses the values of intercultural understanding. With the above examples I have aimed to illustrate how different dimensions of critical literacy, such as examining multiple viewpoints and focusing on sociopolitical issues, can be practiced when reading storybooks. I have also argued that children should be treated as able and competent to make connections, and to challenge the meanings produced in texts and images. Having said that, adults too have an important role, since children need support as critical readers. In the next section I shall briefly examine the role of adults in children's development towards critical literacy.

\section{Teachers and parents supporting children in becoming critical readers}

Based on the contemporary research introduced in this chapter, it seems that the principles of critical literacy are valued among those planning and carrying out formal education. In addition, it is already well-established that critical literacy is among the key skills needed for future generations (see e.g. 
Bajovic and Elliot 2011; Dozier, Johnston and Rogers 2006; Reyes-Torres and Bird 2015). Knowing all this, one could assume that future educators and teachers should receive support and education in developing critical literacy. Instead, the "testing and right answer" heritage of schooling, which is known not to support the development of critical literacies, still dominates in most countries (Lewison, Flint and Van Sluys 2002, 383). In addition, the standardization and accountability that dominate education systems across the world can be seen as a threat to independent thinking and ethical judgment (Phelan, 2015).

Norris, Lucas and Prudhoe (2012) studied early childhood preservice teachers' responses to activities and theories concerning critical literacy. They found that while students were able to see the benefits of critical literacy, challenges emerged. First, students experienced personal anxiety or discomfort in addressing sensitive themes, or "touchy subjects," as Norris et al. called them. Students were also concerned about parents' reactions, and possible opposition towards the issues being addressed. In addition, practical issues, such as the school's curricula, resources, and time were seen as challenges in implementing critical literacy. Norris et al. $(2012,62)$ argue that based on the potential barriers voiced by the preservice teachers, teacher education programs need to be developed to overcome such challenges. In the same manner, Murris (2013) argues that different approaches to reading literature should be promoted as part of teacher education. According to Murris, teacher education should emphasize the opportunities of using literature more. This would further future teachers' knowledge of different reading strategies and different theories of knowledge (Murris 2013).

Rowan and Honan $(2005,219-220)$ also focus on literacy educators. They claim that to critically evaluate their work, literacy educators ought to "examine not only what they include, but also, and most importantly, those people, ideas and perspectives who are silenced and forgotten" to respond to the demands of these complex, changing times. For all educators, not only literacy teachers, it is necessary to critically evaluate whose knowledge and views - as in history, culture, and values - are included, and allowed into our classrooms. Dozier, Johnston and Rogers $(2006,11)$ argue in relation to this, that when teachers' own critical literacy skills and competencies are in focus, the crucial point to remember is that teachers bring with them "deeply socialized discursive histories, highly practiced discursive routines, and tightly woven beliefs, values and discursive practices that do not always frame students productively." Thus, I suggest first, based on Lissa Paul's model $(1998,16)$, a set of questions for adults to examine and analyze the power relations in storybooks. The questions listed below are meant to draw attention to examining agency, as well as to blatant and subtle stereotypes:

Whose story is this? When and where was the reading produced?

Who is named? And who is not?

Who gets punished? And who gets praised?

Who speaks? And who is silenced?

Who acts? And who is acted upon?

In addition, I suggest a list of adapted questions for children. The questions are meant to function as a starting point to discuss and examine stereotypes, racism and power in storybooks with children of different ages:

2-4 years old: What kind of characters are there in the story? Who is the main character? What is the story about?

5-6 years old: What kind of language is used? Are there difficult/hurtful/insulting words? Do the images narrate the same or a different story when compared to the text (i.e., is it a symmetrical, complementary or expanding picturebook?)

7-10 years old: Are the characters stereotypical (in terms of ethnicity, gender or e.g., sexual orientation)? Is there an obvious and/or a hidden moral message?

When supporting young readers in critical literacy, it is fundamental for the adult to accept that readers may disclose different significances to a text according to their already held social attitudes and values. As discussed in the beginning of this chapter, when children are seen as both problem-solvers and problem-posers, adults need to accept that there is not only one right answer, and should allow young readers to produce meanings, and later on, questions. Lewison, Flint and Van Sluys (2002, 383) remind us how we ought to accept that there is, and will be, conflicting answers and opinions when multiple perspectives are allowed. However, to unlearn old practices is not easy (Dozier, Johnston and 
Rogers 2006; Norris et al. 2012). Nevertheless, teachers must be able to address social issues, even the difficult, or "touchy subjects" such as of inequality, racism and sexism that occur in their classrooms, communities, and society at large. As Norris et al. $(2012,62)$ argue, a curriculum which focuses on issues of diversity, such as race, culture, language, and gender, and sees children's questions as important, is both socially just and culturally responsive.

\section{Conclusions}

The ideas suggested in this chapter provide information about the nature and practice of critical literacy. It is essential to ponder how children's literature as texts rooted in sociopolitical discourses can be more efficiently employed in educating children and young people about privilege and unfair structures in society. This chapter aims to illustrate the transformative potential in literature and reading: the potential to teach us to better understand the world, ourselves and others. Children's storybooks can criticize how things are, and through books we can also imagine new and different ways of seeing and being. In line with Ives and Crandall (2014) and Norris et al. (2012), I suggest that critical literacy should be understood to develop intercultural understanding, including an understanding of the way in which language and power affects social relations. Therefore, critical literacy ought to be promoted as contributing to culturally responsive pedagogy, and to fostering social justice. In order to acknowledge differences respectfully, before teaching children how to read with a critical stance, teachers and parents must be willing and able to examine their own subject position critically. 


\section{References}

Agnello E. (2016) I Am Alex. Bumble Books, Noordhoek.

Bajovic M., Elliot A. (2011) The intersection of critical literacy and moral literacy: Implications for practice. Critical Literacy: Theories and Practices 5(1), 27-37.

Baker M., Martin D., Pence H. (2008) Supporting peace education in teacher education programs. Childhood Education 85(1), 20-26.

Bal M. (2002) Travelling concepts in the humanities: A rough guide. University of Toronto Press, Toronto.

Beezmohun S. (2013) Puuttuva peilikuva. Etniset vähemmistöt brittiläisessä lastenkirjallisuudessa. In: Rastas A. (ed.) Kaikille lapsille: Lastenkirjallisuus liikkuvassa, monikulttuurisessa maailmassa. Suomalaisen Kirjallisuuden Seura, Helsinki: 246-263.

Botelho JM., Kabakow Rudman M. (2009) Critical multicultural analysis of children's literature. Routledge, New York.

Bradford C. (2011) Children's literature in a global age: Transnational and local identities. Nordic Journal of ChildLit Aesthetics 2, 20-34.

Bradford C. (2007) Unsettling narratives: Postcolonial readings of children's literature. Wilfrid Laurier University Press, Waterloo.

Broderick DM. (1973) Image of the black in children's fiction. R. R. Bowker, New York.

Cai M. (2002) Multicultural literature for children and young adults: Reflections on critical issues. Greenwood Press, Westport.

Chaudri A., Teale WH. (2013) Stories of multiracial experiences in literature for children, ages 9-14. Children's Literature in Education 44, 359-376.

Comber B. (2013). Critical literacy in the early years: Emergence and sustenance in an age of accountability. In Larson J., Marsh J. (eds) The SAGE Handbook of early childhood literacy. SAGE, London: 587-601.

Cotton P., Daly N. (2015) Visualising cultures: The “European picture book collection” moves “down under”. Children's Literature in Education (2015) 46:88-106.

Crenshaw K. (1991) Mapping the margins: Intersectionality, identity politics, and violence against women of color. Stanford Law Review 43(6), 1241-1299.

Cullingford C. (1998) Children's literature and its effects. Cassel, London.

Dhamoon RK. (2011) Considerations of mainstreaming intersectionality. Political Research Quarterly 64(1), 230-243.

Dozier C., Johnston P., Rogers R. (2006) Critical literacy critical teaching: Tools for preparing responsive teachers. Teachers College Press, New York.

Dudek D. (2011) Multicultural. In: Nel P., Paul L. (eds) Keywords for children's literature. New York University Press, New York: 155-160.

Fjällström E., Kokkola L. (2015) Resisting focalisation, gaining empathy: Swedish teenagers read Irish fiction. Children's Literature in Education 46, 394-409.

Freire P. (1972) Pedagogy of the oppressed (M Bergman Ramos, Transl.). (Original work published 1970) Penguin, Harmondsworth. 
Gunning M. (2004) A Shelter in Our Car. Children’s Books Press, San Francisco.

Hall S. (2013) The work of representation. In: Hall S., Evans J., Nixon S. (eds) Representation. Second edition. SAGE, London: $1-47$.

Huttunen L., Löytty O., Rastas A. (2005) Suomalainen monikulttuurisuus. In: Rastas A., Huttunen L., Löytty O. (eds) Suomalainen vieraskirja: Kuinka käsitellä monikulttuurisuutta. Vastapaino, Tampere: 16-40.

Ives D., Crandall C. (2014) Enacting a Critical Pedagogy of Popular Culture at the Intersection of Student Writing, Popular Culture, and Critical literacy. In: Paugh O., Kress T., Lake R. (eds) Teaching towards Democracy with Postmodern and Popular Culture Texts. Sense Publishers: 201-220.

Kettel P. R. (1993) Understanding homelessness through children's books. Language Arts Journal of Michigan 9(1), 68-75.

Kontio T. (2015) Koira nimeltä Kissa [A Dog Called Cat] (E Warsta Ill.) Teos, Helsinki.

Lewison M., Flint A S., Van Sluys K. (2002) Taking on critical literacy: The journey of newcomers and novices. Language Arts 79(5): 382-392.

Luke A. (2012). Critical Literacy: Foundational Notes. Theory Into Practice 51(5), 4-11.

MacCann, D, Maddy, Y A. (2013) Apartheid and Racism in South African Children's Literature 1985-1995. Routledge, New York.

McCallum R., Stephens J. (2011) Ideology and Children's Books. In: Wolf S., Coats K., Enciso P., Jenkins C. (eds) Handbook of Research on Children's and Young Adult Literature. Routledge, New York: 359-371.

McKee D. (2014) Elmer and the Monster. Andersen Press Ltd., London.

McKee D. (2006) Elmer and Aunt Zelda. Andersen Press Ltd., London.

McKee D. (1986/1989) Elmer. Andersen Press Ltd., London.

McLaughlin M., DeVoogd GL. (2004) Critical literacy as comprehension: Expanding reader response. Journal of Adolescent \& Adult Literacy 48(1), 52-62.

Mendoza J., Reese D. (2001) Examining multicultural picture books for the early childhood classroom: Possibilities and pitfalls. Early Childhood Research \& Practice 3(2).

Murris K. (2013) Reading philosophically in a community of inquiry: Challenging developmentality with Oram and Kitamura's Angry Arthur. Children's Literature in Education 45, 145-165.

May S. (1999) Critical multiculturalism and cultural difference. In: May S. (ed) Critical multiculturalism: Rethinking multicultural and antiracist education. Farmer Press, London: 11-41.

Nieto S. (2010) Language, culture, and teaching: Critical perspectives. Routledge, New York.

Nikolajeva M. (2012) Reading other people's minds through word and images. Children's Literature in Education 43, 273-291.

Nikolajeva M., Scott C. (2006) How picturebooks work. Routledge, New York.

Nodelman P. (2010) Words claimed: Picturebook narratives and the project of children's literature. In: Colomer T., Kümmerling-Meibauer B., Silva-Díaz C. (eds) New directions in picturebook research. Routledge, New York: 11-26

Norris K., Lucas L., Prudhoe C. (2012) Examining critical literacy - Preparing preservice teachers to use critical literacy in the early childhood classroom. Multicultural education 19(2), 59-62. 
Österlund M., Lassén-Seger M., Franck M. (2011) 'Glokal' litteraturhistoria: På väg mot en omvärdering av finlandssvensk barnlitteratur. Barnboken - Journal of Children's Literature Research 34(1), 60-71.

Paul L. (1998) Reading otherways. Calendar Islands, Maine.

Phelan A. (2015) Curriculum theorizing and teacher education. Complicating conjunctions. Routledge, New York.

Perry L., Southwell L. (2011) Developing intercultural understanding and skills: Models and approaches. Intercultural Education 22(6), 453-466.

Pesonen J. (2017) Monikulttuurisuudesta Tatun ja Patun Suomessa: Kansallista tarinaa rakentamassa vai uudenlaista suomalaisuutta tuottamassa? Kirjallisuudentutkimuksen aikakauslehti Avain 3/2017.

Pesonen J. (2015) Multiculturalism as a Challenge in Contemporary Finnish Picturebooks - Reimagining sociocultural categories. Doctoral dissertation, Faculty of Education, University of Oulu.

Rastas A. (2013) Alille, Ainolle, Fatimalle ja Villelle: Suomalainen lapsilukija afrikkalaisten diasporasta. In: Rastas A. (ed.) Kaikille lapsille: Lastenkirjallisuus liikkuvassa, monikulttuurisessa maailmassa. Suomalaisen Kirjallisuuden Seura, Helsinki: 83-114.

Reys-Torres A., Bird AR. (2015) Reshaping curriculum to enhance the relevance of literary competence in children's education. Childhood Education 91(1), 9-15.

Rowan L., Honan E. (2005) Literarily lost: The quest for quality literacy agendas in early childhood education. In: Yelland N. (ed) Critical Issues in Early Childhood Education. Open University Press, Berkshire: 197-223.

Stephens J. (1990) Advocating multiculturalism: Migrants in Australian children's literature after 1972. Children's Literature Association Quarterly 15(4), 180-185.

Stewart S L. (2008) Beyond borders: Reading “other” places in children's literature. Children's Literature in Education 39, 95-105

Stuart-Clark R Publishing material of I am Alex: https://www.printmatters.co.za/tradesheets/tradesheet_146.jpg. Accessed 6 Sept 2017.

The Oxford English Dictionary. Loaded. https://en.oxforddictionaries.com/definition/loadedhttps://en.oxforddictionaries.com/definition/loaded. Accessed 8 Sept 2017.

Todorov T. (2000) Race and racism. In: Back L., Solomos J (eds) Theories of race and racism. Routledge, London: 64-70.

Whelan G. (2001) Homeless Bird. HarperCollins Publishers, New York.

Williams L E. (2010) The Can Man. Lee \& Low Books, New York.

Yokota Y. (1993) Issues in Selecting Multicultural Children's Literature. Language Arts (70), 165-167.

Zipes J. (2002) Sticks and stones: The troublesome success of children's literature from Slovenly Peter to Harry Potter. Routledge, New York. 
The Strength of Story in Early Childhood - Diverse Contexts for Development across Domains 18 
Table 1. Practical Tips for Adults in supporting Critical Literacy for Young Readers ${ }^{1}$
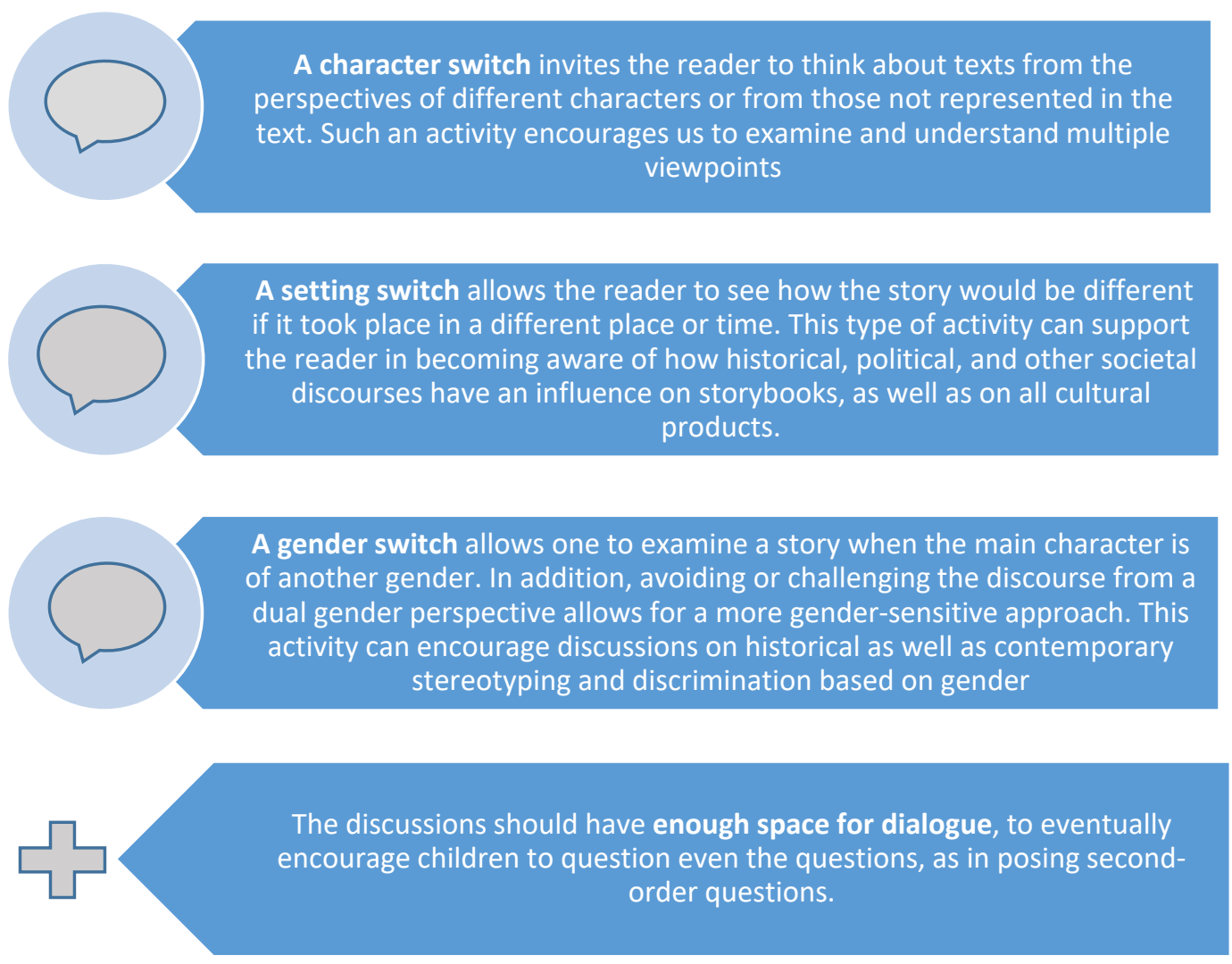

${ }^{1}$ The activities are adapted from McLaughlin and DeVoogd's (2004) model. 


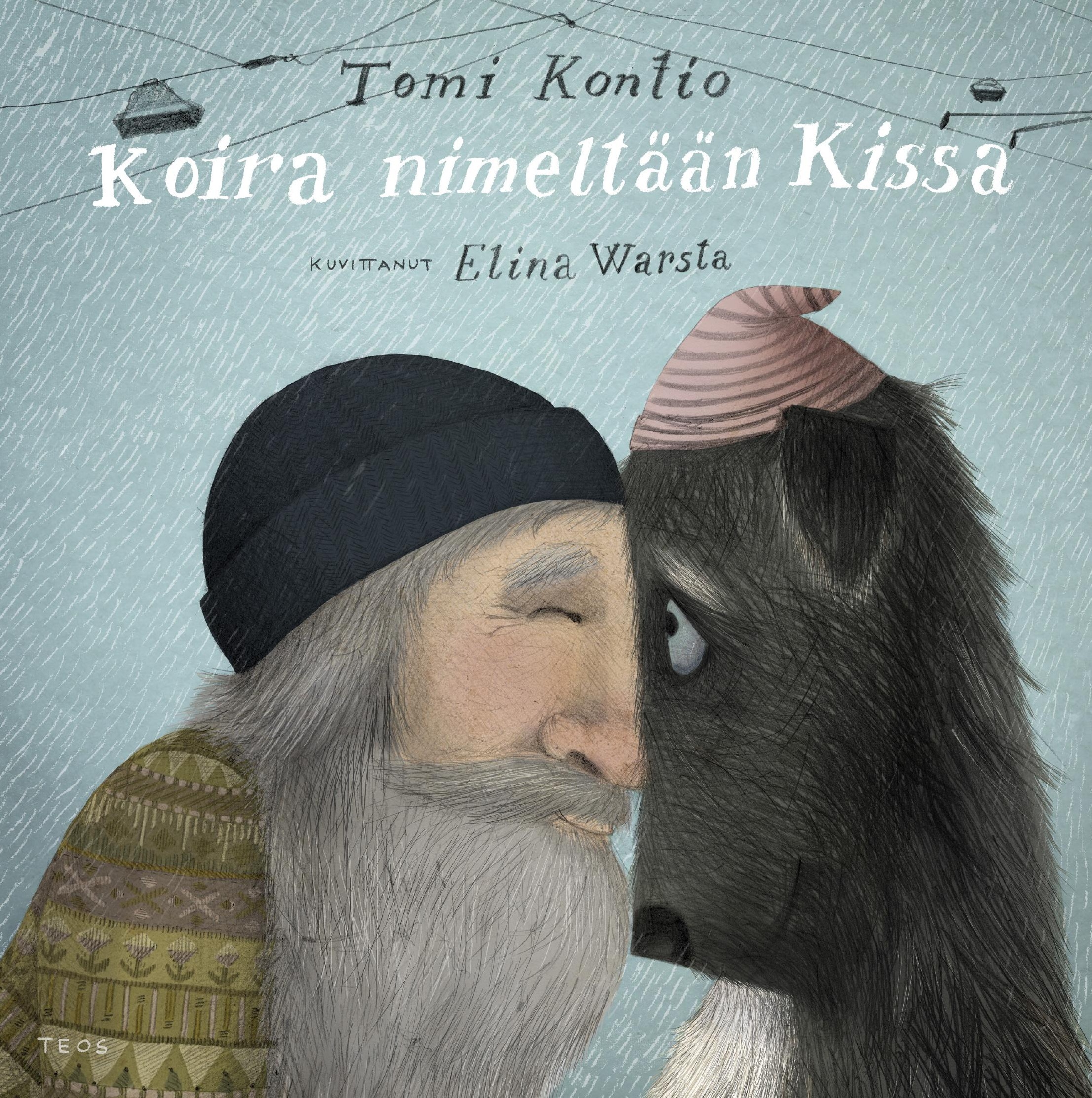




\section{David Mckee}

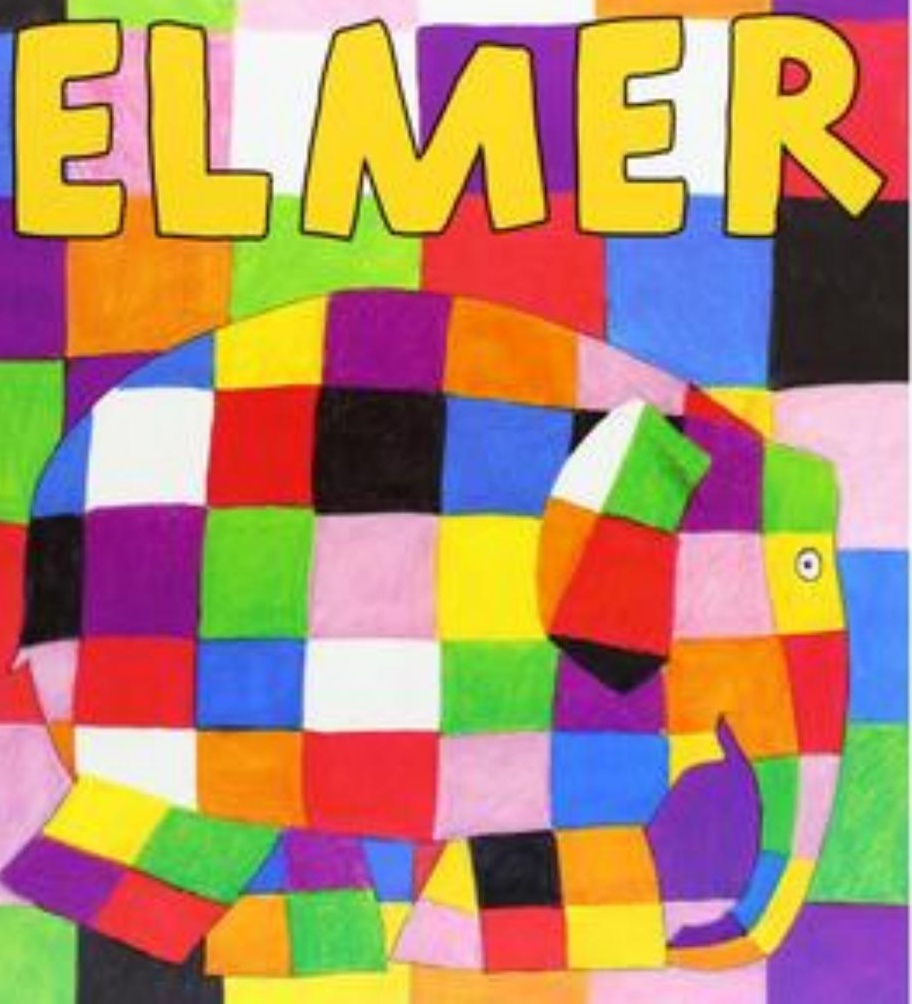

